\title{
Stem cells therapy in acute myocardial infarction: a new era?
}

\author{
R. G. Carbone ${ }^{1} \cdot$ A. Monselise ${ }^{2} \cdot$ G. Bottino $^{1} \cdot$ S. Negrini ${ }^{1} \cdot$ F. Puppo ${ }^{1}(0$
}

Received: 30 September 2020 / Accepted: 4 January 2021 / Published online: 23 January 2021

(c) The Author(s) 2021

\begin{abstract}
Stem cells transplantation after acute myocardial infarction (AMI) has been claimed to restore cardiac function. However, this therapy is still restricted to experimental studies and clinical trials. Early un-blinded studies suggested a benefit from stem cell therapy following AMI. More recent blinded randomized trials have produced mixed results and, notably, the last largest pan-European clinical trial showed the inconclusive results. Furthermore, mechanisms of potential benefit remain uncertain. This review analytically evaluates 34 blinded and un-blinded clinical trials comprising 3142 patients and is aimed to: (1) identify the pros and cons of stem cell therapy up to a 6-month follow-up after AMI comparing benefit or no effectiveness reported in clinical trials; (2) provide useful information for planning future clinical programs of cardiac stem cell therapy.
\end{abstract}

Keywords Stem cells $\cdot$ Bone marrow cells $\cdot$ Acute myocardial infarction $\cdot$ Transplantation $\cdot$ Clinical trials

\section{Introduction}

Transplantation of stem cells by intracoronary infusion after acute myocardial infarction (AMI) represents a novel therapeutic procedure that has been claimed to restore cardiac function. However, the mechanisms underlying its potential efficacy remain unclear. It has been assumed that apoptosis of transplanted cells modulates local immune reactivity deactivating macrophages and dendritic cells and stimulating regulatory $\mathrm{T}$ lymphocytes. These phenomena lead to repressed myocardial cells apoptosis thus improving cardiac outcome [1]. Further mechanisms of repair induced by stem cells that have been demonstrated both in experimental models and humans are related to the self-regeneration properties and plasticity of cardiac tissue including: (1) direct cell

What this study adds in this field This review analytically evaluates un-blinded and blinded clinical trials only. It is an accurate overview based on National Library of Medicine database for clinical trials covering the largest period reported in the literature (from 2000 to 2020), including 3142 cases treated with stem cells transplant after AMI. It analyses the efficacy of stem cell transplantation on LVEF increase 6 months after AMI.

F. Puppo

puppof@unige.it

1 Department of Internal Medicine, University of Genoa, Genoa, Italy

2 Tel Aviv University, Tel Aviv, Israel differentiation from mononuclear cells to cardiac myocytes [2]; (2) cytokine-induced growth of residual viable myocytes [3, 4]; (3) stimulation of resident cardiac stem cells [5]; (4) induction of cell fusion between transplanted stem cells and resident myocytes [6]; and (5) interactions between endothelial cells and cardiomyocytes [7]. Collectively, these mechanisms may lead to a significant increase of perfusion indices and of quality of life.

This article is a systematic review evaluating 34 blinded and un-blinded clinical trials comprising 3142 patients with AMI and is aimed to: (1) identify the pros and cons of stem cell therapy up to a 6-month follow-up after AMI; (2) provide useful information for planning future clinical programs of cardiac stem cell therapy.

\section{Methods}

In order to outline the total number of publications on blinded and un-blinded clinical trials on stem cell therapy in the field of AMI from 2000 to 2020, the search terms "stem cells", "bone marrow cells", "acute myocardial infarction", "transplantation" and "clinical trials" were entered in the search field of the National Library of Medicine database for clinical trials (www.clinicaltrials.gov). A total of 95 studies were registered worldwide, among them 40 were conducted in Europe and 4 in Italy. Phase 1, 2, 3 and 4 studies were $28 \%, 57 \%, 14 \%$ and $1 \%$, respectively. Observational and 
randomized studies were $22 \%$ and $78 \%$, respectively. Clinical setting of enrolled patients was acute coronary syndrome in 43 studies (46\%), heart failure in 29 studies $(30 \%)$ and chronic heart disease in 23 studies (24\%). Among them 34 were blinded and un-blinded clinical trials in AMI patients. In these trials, transplantation of bone marrow-derived cells (BMC) or circulating progenitor cells (CPC), granulocytecolony stimulating factor (G-CSF) mobilized peripheral blood stem cells (PSC), mesenchymal cells (MSC) and allogeneic cardiac stem cells was utilized in 25 (73.5\%), 6 $(17.5 \%), 2(6 \%)$ and 1 (3\%) of cases, respectively. Other cell types were used for transplantation in a minority of studies including endothelial precursor cells in $16 \%$, myoblasts in $2 \%$ and adipoblasts in $1 \%$ of cases, respectively.

\section{End points}

Primary compare per cent increase in mean left ventricular ejection fraction (LFEV) evaluated up to 6 months after stem cells transplantation in AMI.

Secondary compare trials showing benefit or no effectiveness to improve planning of future clinical trials.

\section{PRO: Trials showing benefit of stem cells therapy in AMI}

Reports published in 2002 and 2003 showed for the first time that selective intracoronary transplantation of autologous BMC could be useful in myocardial regeneration and neovascularization beneficially affecting post infarction remodelling processes [8-10].

Subsequent studies confirmed that SC therapy induces: (1) metabolic regeneration of infarcted area and chronic myocardial avital tissue with maximum oxygen uptake increase; (2) improvement in myocardial blood perfusion in the ischaemic region; and (3) durable therapeutic effect and increased exercise capacity in patients with end-stage ischaemic heart disease [11-15].

In BOOST trial, 60 patients with AMI who had undergone percutaneous coronary intervention (PCI) were randomly assigned to $\mathrm{BMC}$ harvest and intracoronary infusion into the infarct-related artery or to a control group [16]. The end point was mean LVEF change from baseline to 6-month follow-up. LVEF was significantly greater in the BMC-infused group than in the control group (6.7 versus 0.7 percentage points, $p=0.0026$ ). The combination with G-CSF therapy and intracoronary PSC infusion further improved cardiac function promoting angiogenesis. However, the occurrence of restenosis represented a serious side effect of this procedure [16]. The transplantation of PSC after G-CSF mobilization (FIRSTLINE-AMI) reduced this complication offering an effective strategy for preservation of myocardium and prevention of remodelling without evidence of restenosis [17]. The potential value of G-CSF in comparison with the combination of G-CSF and PSC was also assessed in the MAGIC trial [18]. Twentyseven patients with AMI undergoing PCI were randomly assigned to PSC mobilization with G-CSF followed by stem cell apheresis and intracoronary reinfusion, to G-CSF alone, or to a control group. Six-month follow-up data in 10 of the study patients demonstrated an improvement in LVEF with PSC infusion (from 48.7 to $55.1 \%$ ) but not with G-CSF alone. PSC infusion also increased treadmill exercise time and reduced the size of the myocardial perfusion defect. However, administration of G-CSF was associated with an unexpectedly high rate of in-stent restenosis of the culprit lesion. The STEM-AMI study recently confirmed that early administration of G-CSF and PSC exerted a beneficial effect in patients with left ventricular dysfunction after ST-segment-elevation myocardial infarction in terms of global systolic function, adverse remodelling, scar size and myocardial strain [19].

In addition, a randomized controlled study demonstrated that mesenchymal stem cells infusion leads to improvement in wall motion and velocity, reduction in ventricular endsystolic and end-diastolic volumes and $14 \%$ net increase in ejection fraction [20]. These results were confirmed by Hare et al. [21] and Kim et al. [22] who reported that intracoronary infusions of bone marrow-derived mesenchymal cells improved LVEF in 53 and 26 post-myocardial infarction patients, respectively.

A number of studies validated SC transplantation as a safe and effective procedure in AMI.

The TOPCARE-AMI trial evaluated the effect on coronary blood flow regulation of intracoronary infusion of BMC or CPC into the infarct-related artery in 59 AMI patients. At 4-month follow-up, coronary flow reserve in the infarct artery was markedly increased up to normal in progenitor cell-treated patients compared with only a moderate improvement in placebo group [23].

A following multicentre trial (REPAIR-AMI), including 204 patients who underwent primary PCI after an ST-elevation AMI, was randomly assigned to receive intracoronary infusion of BMC into the infarct-related artery or placebo medium three to six days after AMI. Primary end point, i.e. the absolute increase in LVEF at four months assessed by serial LV angiograms, was significantly higher with active therapy (5.5 versus 3.0\% with placebo). Subgroup analyses found that the benefit was limited to patients with baseline LVEF $<49 \%$ and to those treated more than 5 days after AMI [24, 25].

The findings of another randomized double-blind controlled trial showed that patients who underwent BMC transfer had a significant per cent reduction in infarct size 
and a better recovery of regional systolic function that may reflect improved infarct remodelling [26].

Similar findings were noted in a no-blinded observational study of 42 consecutive patients who had a myocardial infarction five months to nine years previously. These patients were compared to a representative control group that did not receive cellular therapy. At three months after intracoronary transplantation of autologous BMC, infarct size was reduced by $30 \%$, LVEF increased by $15 \%$ and infarction wall movement velocity increased by $57 \%$. There were no significant changes in the control group [27].

More recent studies including the SCAMI trial that enrolled 42 AMI patients [28] and the PRESERVE-AMI trial [29], the largest study in the USA that enrolled 161 AMI patients with ST-segment elevation, added the evidence that intracoronary infusion of autologous BMC is safe, improves LVEF and reduces risk of death after AMI.

Table 1 summarizes clinical trials showing positive results of stem cells transplantation after AMI.

\section{CONS: Trials showing no benefit of stem cells therapy in AMI}

In contrast with the results reported in the previous paragraph, a series of randomized trials produced mixed and uncertain results on the potential benefit of stem cells therapy in AMI.

In fact, a group of patients with ST elevation AMI undergoing PCI and BMC intracoronary infusion into the infarct-related artery did not show amelioration of LVEF as compared to a control group [26]. However, patients who underwent stem cell transfer had a significant $28 \%$ reduction in infarct size and better recovery of regional systolic function, changes that may reflect improved infarct remodelling [26].

In the BOOST trial mentioned above [16], the increase in mean LVEF was no longer significant at late follow-up at 18 months (5.9 vs 3.1 percentage points), suggesting that the benefit was limited to acceleration of LVEF recovery. Moreover, BMC infusion did not decrease the risk of adverse clinical events such as in-stent restenosis and arrhythmia. Notably, the following BOOST 2 clinical trial in which were enrolled 153 patients showed no significant
Table 1 Clinical trials reporting benefit of stem cells transplantation after acute myocardial infarction

\begin{tabular}{|c|c|c|c|c|c|c|}
\hline Authors & Year & Reference & Trials & Cell source & N. patients & $\begin{array}{l}\text { Mean\% } \\
\text { LVEF } \\
\text { increase }\end{array}$ \\
\hline Strauer BE & 2002 & {$[2]$} & - & $\mathrm{BMC}$ & 10 & 2 \\
\hline Assmus B & 2002 & {$[3]$} & TOPCARE-AMI & CPCBMC & 119 & 8.6 \\
\hline Perin EC & 2003 & [7] & - & $\mathrm{BMC}$ & 21 & 3.2 \\
\hline Britten MB & 2003 & {$[4]$} & TOPCARE-AMI & СРCВMC & 1513 & 5 \\
\hline Chen SL & 2004 & {$[14]$} & - & MSC & 69 & 14 \\
\hline Perin EC & 2004 & {$[8]$} & - & $\mathrm{BMC}$ & 20 & 10 \\
\hline Schachinger V & 2004 & {$[17]$} & TOPCARE-AMI & CPCBMC & 3029 & 8 \\
\hline Wollert KC & 2004 & {$[10]$} & BOOST & $\mathrm{BMC}$ & 60 & 7 \\
\hline Kang HJ & 2004 & {$[12]$} & MAGIC & PSC & 27 & 6.4 \\
\hline Strauer BE & 2005 & {$[5]$} & IACT & $\mathrm{BMC}$ & 18 & 15 \\
\hline Ince $\mathrm{H}$ & 2005 & {$[11]$} & FIRSTLINE-AMI & PSC & 25 & 6 \\
\hline Janssens S & 2006 & {$[20]$} & - & $\mathrm{BMC}$ & 67 & 2.8 \\
\hline Schachinger V & 2006 & {$[18]$} & REPAIR-AMI & $\mathrm{BMC}$ & 204 & 7.3 \\
\hline Hare J & 2009 & {$[15]$} & - & MSC & 53 & 6.4 \\
\hline Wohrle J & 2013 & {$[22]$} & SCAMI & $\mathrm{BMC}$ & 42 & 4 \\
\hline Assmus B & 2014 & [19] & REPAIR-AMI & $\mathrm{BMC}$ & 204 & 2.5 \\
\hline Duan F & 2015 & {$[21]$} & - & $\mathrm{BMC}$ & 42 & 15 \\
\hline Quyyumi AA & 2017 & {$[23]$} & PreSERVE-AMI & $\mathrm{BMC}$ & 281 & 2.2 \\
\hline Kim SH & 2018 & [16] & - & MSC & 26 & 5.4 \\
\hline Achilli F & 2019 & [13] & STEM-AMI & PSC & 161 & 5.1 \\
\hline Total & & & & & 1437 & \\
\hline
\end{tabular}

$B M C$ bone marrow-derived cells, $C P C$ circulating progenitor cells, $M S C$ mesenchymal cells, $P S C$ G-CSF mobilized peripheral blood stem cells 
increase in LVEF between BMC transfused and no transfused patients [30].

A series of studies including the HEBE trial [31], the REGENT trial [32], the MYSTAR trial [33] and the SWISS-AMI trial [34] that enrolled a total of 660 AMI patients showed only a modest or no significant improvement in global and regional LVEF after intracoronary $\mathrm{BMC}$ infusion.

In the ASTAMI trial $[35,36] 100$ patients with AMI undergoing primary PCI were randomly assigned to intracoronary BMC infusion group or to control group. Serial imaging with multiple modalities (echocardiography, single photon emission computed tomography [SPECT] and cardiac magnetic resonance) were performed in each patient at baseline and at six months. No differences in LVEF or infarct size were observed between the two groups, suggesting that stem cell transplantation did not improve AMI outcome.

The ineffectiveness of stem cell transplantation in AMI patients was recently confirmed in CAREMI [37], MiHeart/AMI [38], BAMI [39] and Cardiovascular Cell Therapy Research Network (CCTRN) trials [40] including a total of 665 patients showing no improvement in LV remodelling and LVEF as well as in reducing the time to all-cause mortality.

Table 2 summarizes clinical trials showing uncertain results of stem cells transplantation after AMI.

\section{Discussion}

Several studies have advanced the possibility that multipotent stem cells are capable to directly differentiate into cardiac myocytes and to regulate the crosstalk between endothelial cells, cytokines and cardiac cells, in order to favour coronary angiogenesis and substitute apoptotic dead cells after ischaemic myocardial damage. As in most drug development endeavours, there are phases of premature excitement followed by more realistic expectations. Cardiovascular regenerative/reparative medicine has passed the early phase of enthusiastic optimism and is building its foundations on more scientific evidence.

This review reports the largest number of blinded and unblended trials performed in the last two decades (2000-2020), enrolling a total of 3142 patients, aimed at evaluating the efficacy of stem cells transplantation after AMI.

In most trials, transplanted cells were bone marrowderived cells and in a lower number of trials, transplanted cells were circulating progenitor cells, granulocyte-colony stimulating factor G-CSF mobilized peripheral blood stem cells, mesenchymal cells and allogenic cardiac stem cells.

Despite the large number of patients evaluated results demonstrated uncertain efficacy of stem cell transplantation on LVEF increase determined six months after AMI. In fact, 20 trials including 1437 patients showed a mean 7.2\% LVEF increase while 14 trials including 1705 patients did not show any significant LVEF improvement.
Table 2 Clinical trials reporting uncertain benefit of stem cells transplantation after acute myocardial infarction

\begin{tabular}{|c|c|c|c|c|c|c|}
\hline Author & Year & Reference & Trials & Cells source & N. patients & $\begin{array}{l}\text { Mean \% } \\
\text { LVEF vari- } \\
\text { ation }\end{array}$ \\
\hline Fuchs S & 2003 & [9] & - & $\mathrm{BMC}$ & 10 & $=$ \\
\hline Tse HF & 2003 & {$[6]$} & - & $\mathrm{BMC}$ & 8 & $=$ \\
\hline Janssens S & 2006 & {$[20]$} & - & $\mathrm{BMC}$ & 67 & $<1$ \\
\hline Lunde $\mathrm{K}$ & 2006 & [29] & ASTAMI & $\mathrm{BMC}$ & 50 & $>0.6$ \\
\hline Lunde K & 2007 & [30] & ASTAMI & $\mathrm{BMC}$ & 100 & $=$ \\
\hline Hirsch A & 2008 & {$[25]$} & HEBE & $\mathrm{BMC}$ & 200 & $=$ \\
\hline Tendera $\mathrm{M}$ & 2009 & [26] & REGENT & $\mathrm{BMC}$ & 200 & $=$ \\
\hline Gyongyosi & 2009 & [27] & MYSTAR & $\mathrm{BMC}$ & 60 & $=$ \\
\hline Surder D & 2010 & [28] & SWISS-AMI & $\mathrm{BMC}$ & 192 & $=$ \\
\hline Traverse JH & 2012 & {$[34]$} & TIME & $\mathrm{BMC}$ & 120 & $=$ \\
\hline Wollert KC & 2017 & [24] & BOOST-2 & $\mathrm{BMC}$ & 153 & $<1$ \\
\hline Fernandez-Avilés F & 2018 & {$[31]$} & CAREMI & Cardiac stem cells & 49 & $=$ \\
\hline Nicolau JC & 2018 & {$[32]$} & MiHeart/AMI & $\mathrm{BMC}$ & 121 & $=$ \\
\hline Mathur A & 2020 & [33] & BAMI & BMC & 375 & $=$ \\
\hline Total & & & & & 1705 & \\
\hline
\end{tabular}

$B M C$ bone marrow-derived cells 
One possible explanation of these elusive results could be the different amounts of infused cells. In this regard, studies focused on dose-response analysis after stem cells infusion demonstrate significant reduction in LVEF with higher doses $\left(>83 \times 10^{6}\right.$ cells $)$ compared with lower doses $\left(<43 \times 10^{6}\right.$ cells) $[41,42]$. Another possibility to explain the inconsistency of the results is the source of transplanted cells. In fact, it has been reported that haematopoietic stem cells (i.e. $\mathrm{BMC}, \mathrm{CPC}$ and PSC) are able to migrate directly to sites of injury [43] but do not transdifferentiate into cardiac cells in ischaemic tissue [44] and have a deficient DNA repair system leading to an accelerated cell ageing [45]. Of interest, mesenchymal stem cells can differentiate into endothelial cells, smooth muscle cells and cardiac myocytes [46, 47] release cytokines that promote angiogenesis [48] prevent left ventricle fibrosis [49] and stimulate proliferation and differentiation of resident cardiac stem cells [50].

Moreover, the number of patients enrolled in many clinical trials was not sufficient to reach a statistical significance. For example, the BAMI trial planned to enrol about 3000 patients ended up with 375 patients. The low number of cases was insufficient to reach a statistical significance in mortality among patients and case-control group (7\% and $3.82 \%$, respectively) demonstrating impossible to test the hypothesis that bone marrow mononuclear cells therapy decreases mortality [39].

Therefore, we suggest that the main goals for future trials will identify optimal dose and type of cells to infuse as well as determine the better transplantation protocol including number of enrolled patients, number of treatments and administration via (intravenous or intracoronary).

With this perspective, a large clinical trial with the scope to achieve a consistent response regarding the efficacy of stem cells therapy to renew and repair myocardial damage after acute myocardial infarction is needed. According with the Editorial recently published by Bolli [51] "The most important thing in the post-BAMI era is to keep an open mind and let ourselves be guided by the evidence". Moreover, one of the most important unanswered questions is which clinical conditions (diseases) should be prioritized to increase the probability of therapeutic success.

Funding Open Access funding provided by Università degli Studi di Genova.

\section{Compliance with ethical standards}

Conflict of interest The authors do not have conflict of interest.

Open Access This article is licensed under a Creative Commons Attribution 4.0 International License, which permits use, sharing, adaptation, distribution and reproduction in any medium or format, as long as you give appropriate credit to the original author(s) and the source, provide a link to the Creative Commons licence, and indicate if changes were made. The images or other third party material in this article are included in the article's Creative Commons licence, unless indicated otherwise in a credit line to the material. If material is not included in the article's Creative Commons licence and your intended use is not permitted by statutory regulation or exceeds the permitted use, you will need to obtain permission directly from the copyright holder. To view a copy of this licence, visit http://creativecommons.org/licenses/by/4.0/.

\section{References}

1. Thum T, Bauersachs J, Poole-Wilson PA, Volk HD, Anker SD. The dying stem hypothesis: immune modulation as a novel mechanism for progenitor cell therapy in cardiac muscle. J Am Coll Cardiol. 2005;46:1799-802.

2. Orlic D, Kajstura J, Chimenti S, et al. Bone marrow cells regenerate infarcted myocardium. Nature. 2001;410:701-51.

3. Gnecchi M, He H, Liang OD, et al. Paracrine action accounts for marked protection of ischemic heart by AKT-modified mesenchymal stem cells. Nat Med. 2005;11:367-8.

4. Hodgkinson CP, Bareja A, Gomez JA, Dzau VJ. Emerging concepts in paracrine mechanisms in regenerative cardiovascular medicine and biology. Circ Res. 2016;118:95-107.

5. Anversa P, Leri A, Kajstura J. Cardiac regeneration. J Am Coll Cardiol. 2006;47:1769-76.

6. Plotnikov EY, Silachev DN, Popkov VA, et al. Intercellular signalling cross-talk: to kill, to heal and to rejuvenate. Heart Lung Circ. 2017;26:648-59.

7. Colliva A, Braga L, Giacca M, Zacchigna S. Endothelial cellcardiomyocyte crosstalk in heart development and disease. J Physiol. 2020;598:2923-39.

8. Strauer BE, Brehm M, Zeus T, et al. Repair of infarcted myocardium by autologous intracoronary mononuclear bone marrow cell transplantation in humans. Circulation. 2002;106:1913-8.

9. Assmus B, Schächinger V, Teupe $\mathrm{C}$, et al. Transplantation of progenitor cells and regeneration enhancement in acute myocardial infarction (TOPCARE-AMI). Circulation. 2002;106:3009-17.

10. Britten MB, Abolmaali ND, Assmus B, et al. Infarction remodeling after intracoronary progenitor cell treatment in patients with acute myocardial infarction (TOPCARE-AMI): mechanistic insight from serial contrast-enhanced magnetic resonance imaging. Circulation. 2003;108:2212-8.

11. Strauer BE, Brehem M, Zeus T, et al. Regeneration of human infarcted heart muscle by intracoronary autologous bone marrow cell transplantation in chronic coronary artery disease: the IACT study. J Am Cell Cardiol. 2005;46:1651-8.

12. Tse HF, Kwong YL, Chan Lo G, Ho CL, Lau CP. Angiogenesis in ischaemic myocardium by intramyocardial autologous bone marrow mononuclear cell transplantation. Lancet. 2003;361:47-9.

13. Perin EC, Dohmann HF, Borojevic R, et al. Transendocardial, autologous bone marrow cell transplantation for severe chronic ischemic heart failure. Circulation. 2003;107:2294-302.

14. Perin EC, Dohmann HF, Borojevic R, et al. Improved exercise capacity and ischemia 6 and 12 months after transendocardial injection of autologous bone marrow mononuclear cells for ischemic cardiomyopathy. Circulation. 2004;110(11 Suppl 1):213-8.

15. Fuchs S, Satler LF, Kornowski R, et al. Catheter-based autologous bone marrow myocardial injection in no-option patients with advanced coronary artery disease: a feasibility study. J Am Coll Cardiol. 2003;41:1721-4.

16. Wollert KC, Meyer GP, Lotz J, et al. Intracoronary autologous bone-marrow cell transfer after mycocardial 
infarction: the BOOST randomised controlled clinical trial. Lancet. 2004;364:141-8.

17. Ince $H$, Petzsch $M$, Kleine HD, et al. Preservation from left ventricular remodeling by front-integrated revascularization and stem cell liberation in evolving acute myocardial infarction by use of granulocyte-colony-stimulating factor (FIRSTLINE-AMI). Circulation. 2005;112:3097-106.

18. Kang HJ, Kim HS, Zhang SY, et al. Effects of intracoronary infusion of peripheral blood stem-cells mobilised with granulocyte -colony stimulating factor on left ventricular systolic function restenosis after coronary stenting in myocardial infarction: the MAGIC cell randomized clinical trial. Lancet. 2004;363:751-6.

19. Achilli F, Pontone G, Bassetti B, et al. Stem-AMI outcome CMR Sub-Study Investigators. G-CSF for extensive STEMI. Circ Res. 2019;125:295-306.

20. Chen SL, Fang WW, Ye F, et al. Effect on left ventricular function of intracoronary transplantation of autologous bone marrow mesenchymal stem cell in patients with acute infarction. Am J Cardiol. 2004;94:92-5.

21. Hare JM, Traverse JH, Henry TD, et al. A randomized, doubleblind, placebo-controlled, dose-escalation study of intravenous adult human mesenchymal stem cells (prochymal) after acute myocardial infarction. J Am Coll Cardiol. 2009;54:2277-86.

22. Kim SH, Cho JH, Lee YH, et al. improvement in left ventricular function with intracoronary mesenchymal stem cell therapy in a patient with anterior wall ST-segment elevation myocardial infarction. Cardiovasc Drugs Ther. 2018;32:329-38.

23. Schächinger V, Assmus B, Britten MB. Transplantation of progenitor cells and regeneration enhancement in acute myocardial infarction: final one-year results of the TOPCARE-AMI trial. J Am Coll Cardiol. 2004;44:1690-9.

24. Schächinger V, Erbs S, Elsasser A, et al. Intracoronary bone marrow-derived progenitor cells in acute myocardial infarction. $\mathrm{N}$ Engl J Med. 2006;355:1210-21.

25. Assmus B, Leistner DM, Schächinger V, et al. Long-term clinical outcome after intracoronary application of bone marrow-derived mononuclear cells for acute myocardial infarction: migratory capacity of administered cells determines event-free survival. Eur Heart J. 2014;35:1275-83.

26. Janssens S, Dubois C, Bogaert J, et al. Autologous bone-marrow derived stem cell transfer in patients with ST-segment elevation myocardial infarction: double blind, randomized controlled trial. Lancet. 2006;367:113-21.

27. Duan F, Qi Z, Liu S, et al. Effectiveness of bone marrow mononuclear cells delivered through a graft vessel for patients with previous myocardial infarction and chronic heart failure: an echocardiographic study of left ventricular remodeling. Med Ultrason. 2015;17:160-6.

28. Wöhrle J, von Scheidt F, Schauwecker P, et al. Impact of cell number and microvascular obstruction in patients with bonemarrow derived cell therapy: final results from the randomized, double-blind, placebo controlled intracoronary stem cell therapy in patients with acute myocardial infarction (SCAMI) trial. Clin Res Cardiol. 2013;102:765-70.

29. Quyyumi AA, Vasquez A, Kereiakes DJ, et al. PreSERVE-AMI: A randomized, double-blind, placebo-controlled clinical trial of intracoronary administration of autologous CD34+ cells in patients with left ventricular dysfunction post STEMI. Circ Res. 2017;120:324-31.

30. Wollert KC, Meyer GP, Müller-Ehmsen J, et al. Intracoronary autologous bone marrow cell transfer after myocardial infarction: the BOOST-2 randomised placebo-controlled clinical trial. Eur Heart J. 2017;38:2936-43.

31. Hirsch A, Nijveldt R, van der Vleuten PA, et al. Intracoronary infusion of autologous mononuclear bone marrow cells in patients with acute myocardial infarction treated with primary PCI: Pilot study of the multicenter HEBE trial. Catheter Cardiovasc Interv. 2008;71:273-81.

32. Tendera M, Wojakowski W, Ruzyłło W, et al. Intracoronary infusion of bone marrow-derived selected CD34+CXCR4+ cells and non-selected mononuclear cells in patients with acute STEMI and reduced left ventricular ejection fraction: results of randomized, multicentre myocardial regeneration by intracoronary infusion of selected population of stem cells in acute myocardial infarction (REGENT) trial. Eur Heart J. 2009;30:1313-21.

33. Gyöngyösi M, Lang I, Dettke M, et al. Combined delivery approach of bone marrow mononuclear stem cells early and late after myocardial infarction:the MYSTAR prospective, randomized study. Nat Clin Pract Cardiovasc Med. 2009;6:70-81.

34. Sürder D, Schwitter J, Moccetti T, et al. Cell-based therapy for myocardial repair in patients with acute myocardial infarction: rationale and study design of the SWiss multicenter Intracoronary Stem cells Study in Acute Myocardial Infarction (SWISS-AMI). Am Heart J. 2010;160:58-64.

35. Lunde K, Solheim S, Aakhus S, et al. Intracoronary injection of mononuclear bone marrow cells in acute myocardial infarction. N Engl J Med. 2006;355:1199-209.

36. Lunde K, Solheim S, Aakhus S, et al. Exercise capacity and quality of life after intracoronary injection of autologous mononuclear bone marrow cells in acute myocardial infarction: results from the Autologous Stem cell Transplantation in Acute Myocardial Infarction (ASTAMI) randomized controlled trial. Am Heart J. 2007;154(710):e1-8.

37. Fernández-Avilés F, Sanz-Ruiz R, Bogaert J, et al. Safety and efficacy of intracoronary infusion of allogeneic human cardiac stem cells in patients with ST-segment elevation myocardial infarction and left ventricular dysfunction. Circ Res. 2018;123:579-89.

38. Nicolau JC, Furtado RHM, Silva SA, et al. Stem-cell therapy in ST-segment elevation myocardial infarction with reduced ejection fraction: A multicenter, double-blind randomized trial. Clin Cardiol. 2018;41:392-9.

39. Mathur A, Fernández-Avilés F, Bartunek J, et al. The effect of intracoronary infusion of bone marrow-derived mononuclear cells on all-cause mortality in acute myocardial infarction: the BAMI trial. Eur Heart J. 2020;41:3702-10.

40. Traverse JH, Henry TD, Pepine CJ, et al. Effect of the use and timing of bone marrow mononuclear cell delivery on left ventricular function after acute myocardial infarction: the TIME randomized trial. JAMA. 2012;308:2380-9.

41. Mathiasen AB, Qayyum AA, Jørgensen E, et al. Bone marrowderived mesenchymal stromal cell treatment in patients with ischaemic heart failure: final 4-year follow-up of the MSC-HF trial. Eur J Heart Fail. 2020;22:884-92.

42. Bolli R, Kahlon A. Time to end the war on cell therapy. Eur J Heart Fail. 2020;22:893-989.

43. Hastings CL, Roche ET, Ruiz-Hernandez E, et al. Drug and cell delivery for cardiac regeneration. Adv Drug Deliv Rev. 2015;84:85-106.

44. Murry CE, Soonpaa MH, Reinecke H, et al. Haematopoietic stem cells do not transdifferentiate into cardiac myocytes in myocardial infarcts. Nature. 2004;428:664-8.

45. Kang HJ, Kang WS, Hong MH, et al. Involvement of miR-34c in high glucose-insulted mesenchymal stem cells leads to inefficient therapeutic effect on myocardial infarction. Cell Signal. 2015;27:2241-51.

46. Oswald J, Boxberger S, Jorgensen B, et al. Mesenchymal stem cells can be differentiated into endothelial cells in vitro. Stem Cells. 2004;22:377-434.

47. Toma C, Pittenger MF, Cahill KS, et al. Human mesenchymal stem cells differentiate to a cardiomyocyte phenotype in the adult murine heart. Circulation. 2002;105:93-8. 
48. Tang YL, Zhao Q, Zhang YC, et al. Autologous mesenchymal stem cell transplantation induce VEGF and neovascularization in ischemic myocardium. Regul Pept. 2004;117:3-10.

49. Pittenger MF, Martin BJ. Mesenchymal stem cells and their potential as cardiac therapeutics. Circ Res. 2004;95:9-20.

50. Hatzistergos KE, Quevedo H, Oskouei BN, et al. Bone marrow mesenchymal stem cells stimulate cardiac stem cell proliferation and differentiation. Circ Res. 2010;107:913-22.
51. Bolli R. Cell therapy for acute myocardial infarction: requiescat in pace. Eur Heart J. 2020;41:3711-4.

Publisher's Note Springer Nature remains neutral with regard to jurisdictional claims in published maps and institutional affiliations. 